\title{
$14 \mathrm{q} 13.3$
}

National Cancer Institute

\section{Source}

National Cancer Institute. 14913.3. NCI Thesaurus. Code C44957.

Part of the chromosome bands present on the long (q) arm of chromosome 14. 